\title{
Performance of WSSV-infected and WSSV-negative Penaeus monodon postlarvae in culture ponds
}

\author{
Shao-En Peng ${ }^{1}$, Chu-Fang Lo ${ }^{1}$, San-Ching Lin ${ }^{1}$, Li-Li Chen ${ }^{1}$, Yun-Shiang Chang ${ }^{1}$, \\ Kuan-Fu Liu ${ }^{2}$, Mao-Sen $\mathrm{Su}^{2}$, Guang-Hsiung Kou ${ }^{1, *}$ \\ ${ }^{1}$ Department of Zoology, National Taiwan University, Taipei, Taiwan, ROC \\ ${ }^{2}$ Tungkang Marine Laboratory, Taiwan Fisheries Research Institute, Tungkang, Pingtung, Taiwan, ROC
}

\begin{abstract}
In a survey of 27 Penaeus monodon culture ponds stocked with postlarvae ( PL10) at medium density $\left(\sim 40\right.$ shrimp $\left.\mathrm{m}^{-2}\right)$, single-step nested white spot syndrome virus (WSSV) PCR was used to measure the WSSV infection rates in the shrimp populations within 1 mo after stocking. Seven ponds were initially WSSV-free, and the shrimp in 5 of these were harvested successfully. In the ponds $(n=6)$ where detection rates were higher than $50 \%$, mass mortality occurred during the growth period, and none of these ponds was harvested successfully. In a subsequent study, $P$. monodon brooders were classified into 3 groups according to their WSSV infection status before and after spawning: brooders that were WSSV-positive before spawning were assigned to group $\mathrm{A}_{\text {; spawners }}$ that became WSSV-positive only after spawning were assigned to group $\mathrm{B}_{\text {; }}$ and group C consisted of brooders that were still WSSV-negative after spawning. WSSV screening showed that 75, 44 and $14 \%$, respectively, of group A, B and C brooders produced nauplii that were WSSV-positive. Most $(57 \% ; 16 / 28)$ of the brooders in group A produced nauplii in which the WSSV prevalence was high ( $>50 \%$ ). When a pond was stocked with high-prevalence nauplii from 1 of these group A brooders, an outbreak of white spot syndrome occurred within $3 \mathrm{wk}$ and only $\sim 20 \%$ of the initial population survived through to harvest (after $174 \mathrm{~d}$ ). By contrast, 2 other ponds stocked with low-prevalence and WSSV-negative nauplii (derived respectively from 2 brooders in group B), both had much higher survival rates $(70$ to $80 \%)$ and yielded much larger ( $3 \times$ by weight) total harvests. We conclude that testing the nauplii is an effective and practical screening strategy for commercially cultured $P$. monodon.
\end{abstract}

KEY WORDS: White spot syndrome virus · WSSV · Single-step nested WSSV PCR · Predictive power of screening $\cdot$ Penaeus monodon

\section{INTRODUCTION}

White spot syndrome (WSS) continues to be one of the most serious disease problems faced by the shrimp farming industry in Taiwan (Chou et al. 1995, Hsu et al. 1999). The causative agent, WSS virus (WSSV), is widespread, and this shrimp disease is being fought in both the western and the eastern hemispheres, especially in Southeast Asia, North America and Latin America, where there is intensive shrimp culture activity (Global Aquaculture Alliance 1999a,b). Outbreaks of WSS occur rapidly, often lead to $100 \%$ mortality and

*Corresponding author. E-mail: ghkou@ccms.ntu.edu.tw are notoriously hard to predict (Chou et al. 1995, Lo \& Kou 1998, Peng et al. 1998). One of our previous investigations, for instance, found that mass mortality occurs at some time during the growth period in any pond stocked with WSSV-infected postlarvae (Lo et al. 1998), whereas another study (Tsai et al. 1999) found that under some conditions, a WSSV-infected shrimp population can be cultured for a long period $(13 \mathrm{mo})$ without any outbreak of WSS. In the present study, therefore, we used a highly sensitive and specific WSSV diagnostic PCR to evaluate the predictive power of several screening strategies. Similar WSSV diagnostic PCRs are now becoming widely available and some are in kit form and have already been used to screen 
reservoir hosts (Lo et al. 1996, Flegel 1997, Maeda et al. 1998, Lo et al. 1999, Otta et al. 1999), spawners (Hsu et al. 1999, Satoh et al 1999) and shrimp larvae (Tsai et al. 1999), as well as to monitor cultured shrimp populations and estimate the chances of a WSS outbreak (Lo et al. 1998, Withyachumnarnkul 1999).

In the first part of this study, single-step, nested WSSV PCR was used to measure the initial WSSV infection rates in 27 separate Penaeus monodon culture ponds, and these initial WSSV infection patterns were then related to the ultimate fate (successful harvest vs WSS outbreak) of the shrimp population in each pond. This survey showed that while the highest proportion of successful harvests was in ponds where the populations were WSSV free, successful harvests could also be obtained from ponds where the WSSV prevalence rate was below 50\%. This suggested that if the initial WSSV infection was only relatively light, under suitable conditions, shrimp populations might still be successfully cultured through to harvest. To investigate some of the parameters of this possibility, in the next part of the study, a screening method developed by Hsu et al. (1999) was applied to brooders and batches of their eggs and nauplii. These offspring were then classified not only according to their own WSSV infection level but also according to the infection level of the brooder that spawned them. Batches of P. monodon fry that were screened and classified in this way were then cultured through to harvest to allow the predictive power of the screenings to be tested.

\section{MATERIALS AND METHODS}

Influence of initial WSSV infection rates on the successful culture of Penaeus monodon. Postlarvae ( PL10) of Penaeus monodon produced from different local hatcheries were cultured at a density of $\sim 40$ shrimp $\mathrm{m}^{-2}$ (range 15 to 80 shrimp $\mathrm{m}^{-2}$ ) in 27 individual earthen ponds located in different places around Tainan in southern Taiwan. Stocking began in March and culturing continued to June 1998 to give a culture period of about 3 to 4 mo. Shrimp were fed an artificial diet during their growth period. Within 1 mo of stocking, and again when the ponds were either harvested or abandoned, samples of shrimp ( $\mathrm{n}=10$ to 20) were collected with an umbrella net (feeding tray), immediately frozen on dry ice, packed in styrofoam boxes filled with dry ice and transported to the laboratory for WSSV detection. A DNA extraction kit (AcuGen Asia, Taipei, Taiwan) was used to prepare PCR templates from the tested specimens. WSSV was detected with single-step nested PCR using a WSSV specific sequence amplification kit (Farming Intelligene Tech., Taipei, Taiwan) as described previously (Lo et al. 1998). Briefly, this kit uses the principle of competitive PCR to grade WSSV infections into 4 levels of severity. Levels 1 through 4 (very severe infection through to very light infection) correspond respectively to $>2 \times$ $10^{3}, 2 \times 10^{3}, 2 \times 10^{2}$ and $2 \times 10^{1}$ copies of WSSV DNA template in the initial PCR reaction mixture. The positive controls in Fig. 1 show examples of the 4 levels of infection.

Detection of WSSV by single-step nested WSSV PCR in Penaeus monodon brooders and their offspring. Mature Penaeus monodon brooders were captured randomly from the coastal waters around southern Taiwan either in April 1998 or from August 1998 to March 1999. They were immediately transported to the Tungkang Marine Laboratory of the Taiwan Fisheries Research Institute in Pingtung Prefecture, and upon arrival, a pleopod was removed from each shrimp. To minimize handling stress and collateral damage during pleopod removal, each brooder was wrapped in a wet towel so that only the appendage to be removed remained exposed. The pleopod was then

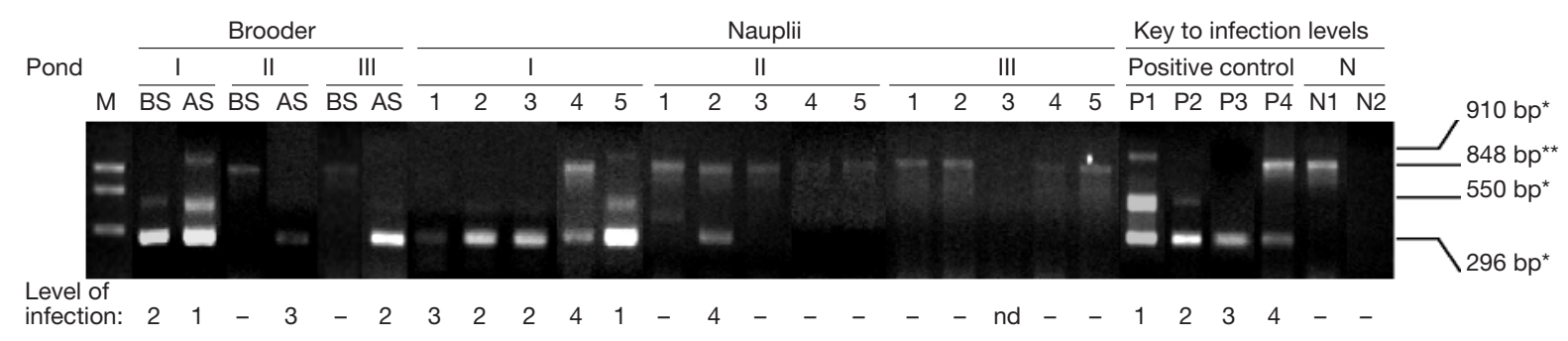

Fig. 1. White spot syndrome virus (WSSV) status of 3 brooders and their nauplii before the offspring were cultured in experimental ponds. The brooder whose offspring were used to stock pond I was WSSV-positive both before (BS) and after spawning (AS). The other 2 brooders were WSSV-positive only after spawning. All 5 of the tested batches of nauplii from the first brooder were WSSV-positive (1 at level 1, 2 at level 2, 1 at level 3 and 1 at level 4 ), but only 1 of the tested batches from the other 2 brooders was WSSV-positive (lane II, 2; level 4). Positive control: the 4 infection levels respectively correspond to $>2 \times 10^{3}, 2 \times 10^{3}, 2 \times 10^{2}$ and $<2 \times 10$ copies of WSSV DNA template in the initial PCR reaction mixture. Negative control: N1, WSSV PCR-negative shrimp; N2, yeast tRNA $\left(40 \mathrm{ng}^{-1} \mathrm{l}^{-1}\right.$ ). ${ }^{*}$ WSSV DNA-specific PCR product. ${ }^{* *}$ Shrimp DNA-specific PCR product. M: DNA size markers of 848 , 630 and $333 \mathrm{bp}$ 
excised with a red-hot pair of forceps in a manner similar to that for eyestalk ablation. DNA was extracted from each removed pleopod using the DNA extraction kit and then subjected to single-step nested WSSV PCR. Subsequently, the brooders were maintained in reproduction facilities (1 brooder in each $500 \mathrm{l}$ fiberglass-reinforced plastic tank containing $450 \mathrm{l}$ aerated, filtered $33 \%$ salinity seawater at $30 \pm 1^{\circ} \mathrm{C}, \mathrm{pH} 8.3$ ) for spawning. A few hours after spawning, the brooders were transferred to new tanks (1 brooder in each 671 fiberglass-reinforced plastic tank containing 501 aerated, filtered $33 \%$ salinity seawater at $30 \pm 1^{\circ} \mathrm{C}$, $\mathrm{pH}$ 8.3) to prevent transmission of WSSV infection or contamination by non-vertical pathways. At the same time, another pleopod was excised, from which DNA was extracted and subjected to single-step nested WSSV PCR as described above. For each brooder, fertilized egg samples ( 50 $\mu \mathrm{l})$ were collected in a microtube and subjected to DNA extraction and single-step nested WSSV PCR. The remaining eggs were allowed to hatch, and nauplii were collected 2 to $4 \mathrm{~h}$ after hatching. To facilitate collection, aeration was stopped for 20 to 30 min to allow the freshly hatched nauplii, which swim intermittently and are positively phototactic, to aggregate at the surface of the water. Collected samples $(50 \mu \mathrm{l})$ were put into microtubes, and subjected to DNA extraction and single-step nested WSSV PCR.

Growth and survival of Penaeus monodon postlarvae derived from WSSV-infected and WSSV-negative nauplii. The offspring of 3 different brooders were selected based on the WSSV detection rates in samples of their nauplii. Single-step nested WSSV PCR showed that 1 of the brooders was WSSV-positive both before and after spawning and the other 2 became WSSVpositive only after spawning (Fig. 1). The nauplii from the first brooder had a high WSSV detection rate ( $\geq 50 \%$ of the tested samples were WSSV-positive); the nauplii from the second had a low WSSV detection rate (less than $50 \%$ of the tested samples were WSSV-positive); and the nauplii from the third brooder were all WSSV-negative (Fig. 1). These 3 batches of nauplii were cultured separately in three 5001 fiberglass-reinforced plastic tanks containing $450 \mathrm{l}$ aerated, filtered $33 \%$ salinity seawater at $30 \pm 1{ }^{\circ} \mathrm{C}, \mathrm{pH} 8.3$. The larvae were fed cultured algae (Isochrysis galbana, Chaetoceros gracilis, Tetraselmis chui) once daily and a commercial , artificial, microparticulated diet 3 times daily. In addition to the commercial diet, the postlarvae were fed WSSV-negative brine shrimp nauplii once daily. The offspring whose nauplii samples had high and low WSSV detection rates were stocked in ponds I (PL9; $\mathrm{n}=5000$ ) and II (PL11; $\mathrm{n}=5000)$, respectively. Pond III was stocked with 5800 WSSV-negative Penaeus monodon seeds at the PL4 stage. The experimental ponds used in this study were in an isolated location in the Tungkang Marine Laboratory of the Taiwan Fisheries Research Institute in Pingtung Prefecture. These $10 \times$ $10 \mathrm{~m}$ ponds had vertical concrete walls, were $1 \mathrm{~m}$ deep and had a 10 to $15 \mathrm{~cm}$ layer of sand on the bottom. The ponds were isolated from each other but shared the same beach-filtered water supply system. Before stocking, the ponds were thoroughly drained of all water and allowed to dry out in the sun for 2 to 6 mo. Two days before stocking, beach-filtered seawater was introduced to each pond through PVC pipes, and the water was aerated with blowers. Throughout the culture period, salinity was 30 to $33 \%$ and the average temperature of the surface water was 25 to $27^{\circ} \mathrm{C}$ in the morning. To avoid contamination, separate equipment and supplies were used for each pond. Only artificial feed was used and no other chemicals or additives were given. Equal measures of feed were distributed by hand at evenly spaced stations along the sides of the pond, 3 times daily, at 09:00 to 10:00, 17:00 to 18:00 and 23:00 to 24:00 h. During feeding, an additional extra-large measure of feed (about $120 \%$ of the usual measure) was spread in an umbrella net (feeding tray) placed in the pond, and the amount of feed offered at the next meal was adjusted according to how much was left on the umbrella net $2 \mathrm{~h}$ after feeding: if more than half of the extra feed remained uneaten, the next meal was reduced by $1 / 4$ to $1 / 3$; if 10 to $50 \%$ of the extra feed remained, the net was checked again just before next feeding and if uneaten feed was still observed, the next meal was again reduced by $1 / 4$ to $1 / 3$; if less than $10 \%$ was left, the same amount of feed was offered. Once the feed consumption ceiling was determined, the amount of feed was subsequently increased by 20 to $25 \%$ twice weekly. After 6 mo of culture, ponds were harvested by using a bag net installed at the drain gate during draining. The body weight of each shrimp was measured, and the average body weight, weight distribution, total crop, feed conversion ratio and the coefficient of variation of harvest weight for each pond were calculated. The feed conversion ratio was calculated by dividing the total feed requirement by the weight gained (total crop minus initial biomass). The coefficient of variation was calculated by dividing the standard deviation of the individual weights by the average of the individual weights.

\section{RESULTS}

\section{Influence of initial WSSV infection rates on the successful culture of Penaeus monodon}

In the first month after stocking, WSSV detection rates were higher than $50 \%$ in 6 of the ponds (group I 
Table 1. Initial white spot syndrome virus (WSSV) infection rates and harvest outcome for cultured Penaeus monodon

\begin{tabular}{|c|c|c|c|c|c|}
\hline Group & $\begin{array}{l}\text { WSSV detection rate within } \\
1 \text { mo after stocking }(\%)^{\mathrm{a}}\end{array}$ & $\begin{array}{l}\text { Stocking density/range } \\
\text { (No. of shrimp } \mathrm{m}^{-2} \text { ) }\end{array}$ & No. of ponds & $\begin{array}{c}\text { No. of ponds } \\
\text { successfully harvested }\end{array}$ & $\begin{array}{c}\text { Percentage of } \\
\text { successful harvest }\end{array}$ \\
\hline I & $\geq 50$ & $48 / 30-80$ & 6 & 0 & 0 \\
\hline II & $1-49$ & $41 / 15-75$ & 14 & 6 & 42.9 \\
\hline III & 0 & $36 / 30-51$ & 7 & 5 & 71.4 \\
\hline
\end{tabular}

ponds; Table 1); Three of these group I ponds had at least 1 specimen with a level 1 or level 2 infection. Fourteen ponds had initial detection rates between 1 and $49 \%$ (group II ponds; all WSSV-positive specimens in these ponds had only a level 4 infection), and the other 7 ponds (group III ponds) were WSSV-negative. The group I ponds were all abandoned before harvest, but 43 and $71 \%$ of the group II and group III ponds, respectively, were harvested successfully. In all the abandoned culture ponds, the clinical signs of WSS such as obvious white spots in the carapace of the diseased shrimp, lethargy and the gathering of affected shrimp around the edges of ponds were observed, and follow-up WSSV PCR tests subsequently confirmed that mortalities were due to outbreaks of WSS (data not shown).

\section{Detection of WSSV by single-step nested WSSV PCR in Penaeus monodon brooders and their offspring}

The WSSV detection rate in mature Penaeus monodon brooders captured from coastal waters around southern Taiwan was $55 \%$ (28/51) before spawning and $87 \%$ (46/53) after spawning. Only $13 \%$ (7/53) of the brooders were WSSV PCR-negative after spawning (Table 2). Following Hsu et al. (1999), these brooders were assigned to 1 of 3 groups according to their WSSV infection status before and after spawning: group A comprised brooders which were WSSV PCRpositive before spawning; group B comprised brooders that were WSSV PCR-positive only after spawning; and group C comprised brooders that were still WSSV PCR-negative after spawning.

The percentages of spawners in each group whose eggs tested WSSV-positive were $75 \%(12 / 16), 50 \%$ $(3 / 6)$ and $0 \%(0 / 3)$, respectively (Table 2$)$. The percentages of spawners whose nauplii tested WSSV-positive were $75 \%(21 / 28), 44.4 \%(8 / 18)$ and $14.3 \%(1 / 7)$, respectively (Table 2). A high WSSV detection rate ( $\geq 50 \%$ of the tested batches from each brooder were WSSV PCR-positive) was found in nauplii from 16 of the 28 brooders in group A. In nauplii derived from brooders in groups B and C, either WSSV detection rates were low $(<50 \%$ of the tested batches from each brooder were WSSV PCR-positive) or WSSV was not found at all.

\section{Growth and survival of WSSV-infected and WSSV-negative Penaeus monodon}

The shrimp in each pond were cultured to market size (culture period: 173 to $174 \mathrm{~d}$ ). When harvested, all shrimp in the 3 ponds appeared healthy and active. The survival rates in pond II (low WSSV detection rate) and pond III (WSSV-negative) were 79.8 and $71.2 \%$, respectively (Table 3 ) compared with a $19.3 \%$ survival rate in pond I (high WSSV detection rate). The feed conversion ratios in ponds I, II and III were 2.3, 1.94 and 1.81, respectively. The total crops in ponds II and III were good (102.9 and $88 \mathrm{~kg}$, respectively), whereas the low total crop $(32.7 \mathrm{~kg})$ in pond I was due to the low survival rate. Normal size distribution was observed in all 3 ponds (Fig. 2).

\section{DISCUSSION}

As our pond survey data (Table 1) suggest, initial WSSV detection (prevalence) rates can be used to predict the fate of the respective cultured shrimp populations. Even under the low to medium culture density conditions in these ponds, none of the shrimp populations with a WSSV detection rate above $50 \%$ was cultured through to harvest, whereas about half of the ponds with lower initial WSSV prevalence rates and $70 \%$ of the WSSV-negative cultures were harvested successfully. In a similar study in Thailand, Withyachumnarnkul (1999) also reported a success rate of about $70 \%$ for Penaeus monodon populations whose fry were initially WSSV-negative; however, in marked contrast to the present study, in almost all of the ponds in which WSSV was found, an outbreak of WSS occurred about 40 to $45 \mathrm{~d}$ after WSSV was first detected in the shrimp population (Withyachumnarnkul 1999). One possible reason for this discrepancy is that although the 1-step WSSV PCR test used by Withyachumnarnkul (1999) used a small amplicon and was thus quite sensitive, it was still not as sensitive 
Table 2. Detection of WSSV by single-step nested WSSV PCR in 53 Penaeus monodon brooders and their offspring. Level 1 $(++++)$, level $2(+++)$, level $3(++)$ and level $4(+)$ infections correspond respectively to $>2 \times 10^{3}, 2 \times 10^{3}, 2 \times 10^{2}$ and $2 \times 10^{1}$ copies of WSSV DNA template in the initial PCR reaction mixture. (-) WSSV PCR-negative. H (high detection rate): $>50 \%$ of tested samples were WSSV PCR-positive; L (low detection rate): $<50 \%$ of tested samples were WSSV PCR-positive; ND: not detected; DF (detection failure): neither WSSV nor shrimp DNA-specific products were obtained

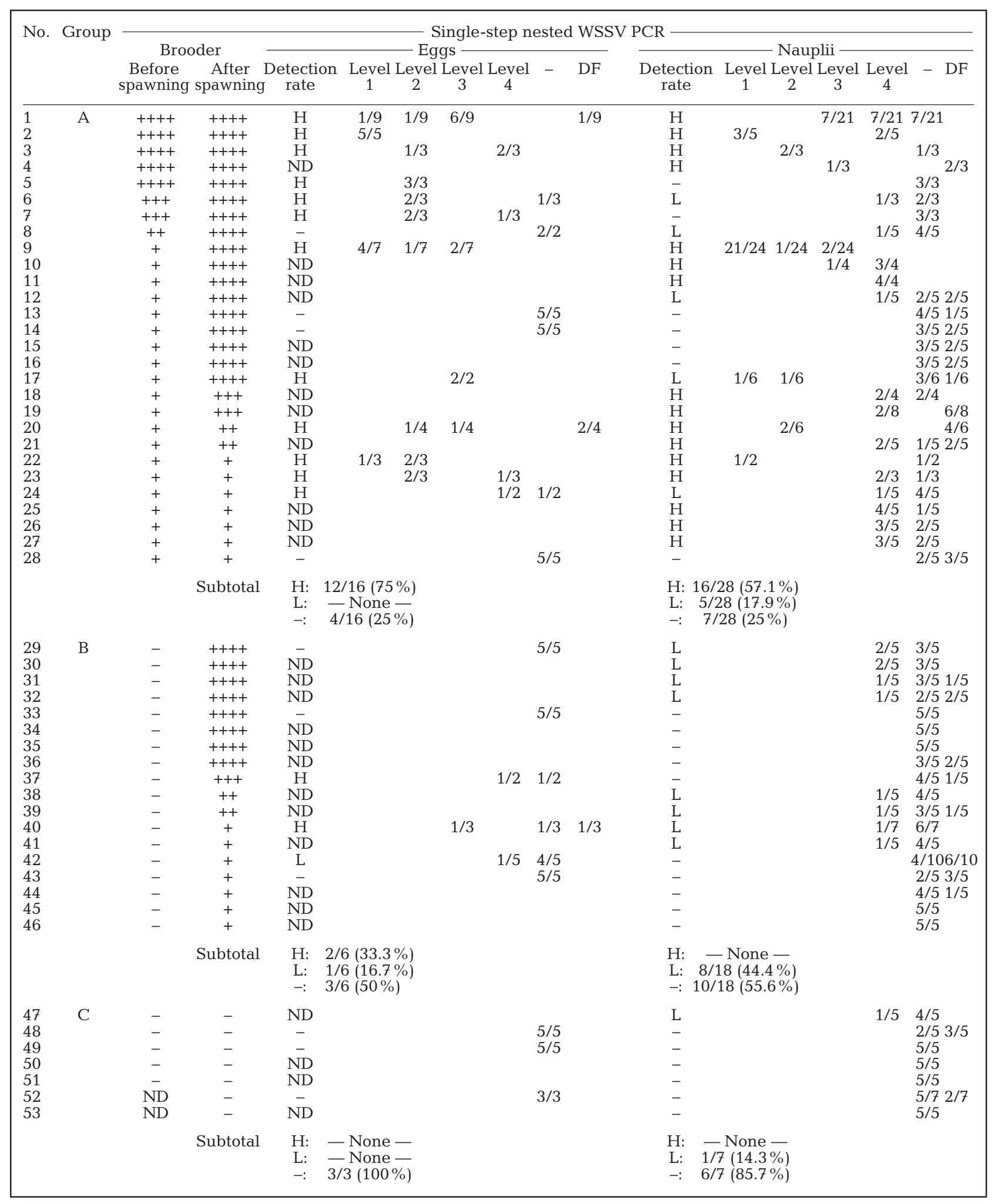


Table 3. Production data from WSSV-infected and WSSVnegative Penaeus monodon cultured in experimental ponds $(10 \times 10 \mathrm{~m})$. Before stocking, batches of nauplii were tested with WSSV single-step nested PCR. High: $>50 \%$ of tested samples were WSSV-positive; Low: $<50 \%$ of tested samples were WSSV-positive

\begin{tabular}{|lccc|}
\hline \multirow{2}{*}{ Parameter } & \multicolumn{3}{c|}{ WSSV detection rate of nauplii } \\
& $\begin{array}{c}\text { High } \\
\text { (pond I) }\end{array}$ & $\begin{array}{c}\text { Low } \\
\text { (pond II) }\end{array}$ & $\begin{array}{c}\text { Negative } \\
\text { (pond III) }\end{array}$ \\
\hline $\begin{array}{l}\text { Density (no. m }{ }^{-2} \text { ) } \\
\text { Duration (d) }\end{array}$ & 50 & 50 & 58 \\
$\begin{array}{l}\text { Mean growth rate of } \\
\quad \text { survivors (g wk }{ }^{-1} \text { ) }\end{array}$ & 174 & 173 & 174 \\
$\begin{array}{l}\text { Feed conversion ratio } \\
\text { Harvest coefficient of }\end{array}$ & 2.3 & 1.04 & 0.86 \\
$\quad$ variation (\%) & 17.6 & 28.6 & 21.1 \\
$\begin{array}{l}\text { Average body weight (g) } \\
\text { Survival (\%) }\end{array}$ & 34 & 25.8 & 21.3 \\
Total crop (kg) & 19.3 & 79.8 & 71.2 \\
& 32.7 & 102.9 & 88 \\
\hline
\end{tabular}

as the nested PCR used in the present study, and this may have resulted in a higher number of false negatives. To some extent, this explanation is corroborated
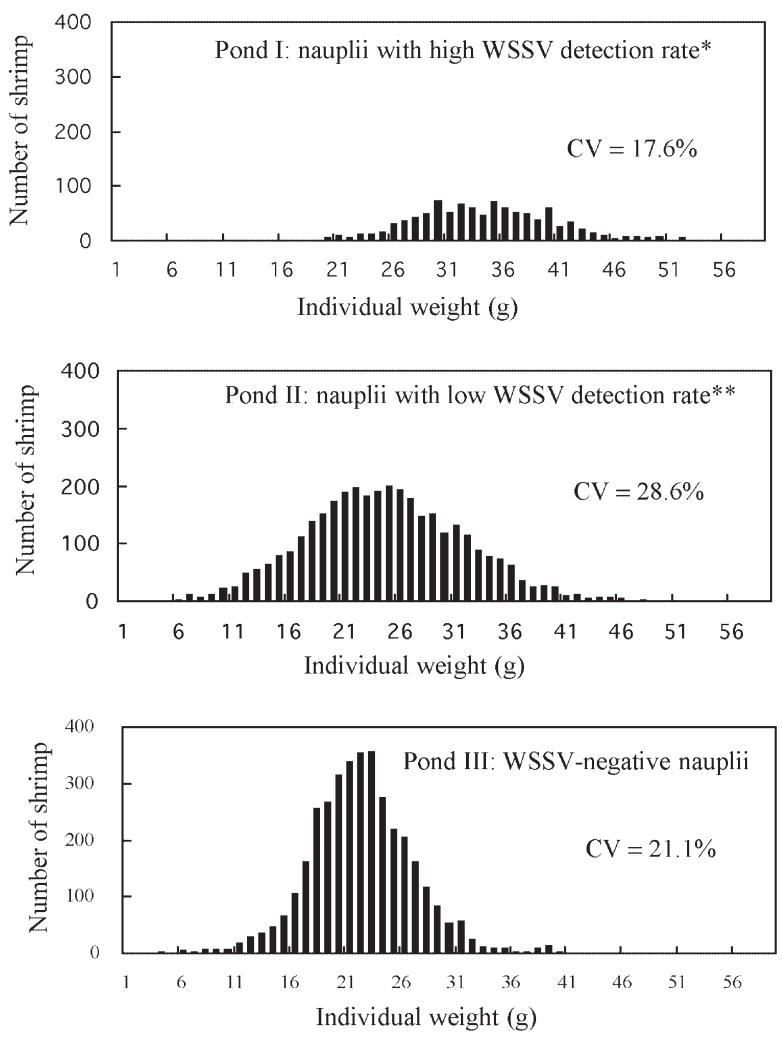

Fig. 2. Weight distribution of Penaeus monodon derived from WSSV-infected or WSSV-negative nauplii 6 mo after stocking. ${ }^{*}>50 \%$ of tested samples were WSSV-positive; ${ }^{* *}<50 \%$ of tested samples were WSSV-positive. CV (\%): coefficient of variation in harvest weight by the finding that, although Taiwan and Thailand are in the same WSS epizootic area, WSSV detection rates were much higher in the present study: $74 \%(20 / 27)$ compared with $23 \%$ (43/188) in the Thailand study. Clearly, if WSSV was being detected in Withyachumnarnkul's (1999) study only when infection levels were already relatively high, this would explain why so many of these WSSV-positive ponds succumbed to an outbreak of WSS within 6 to $7 \mathrm{wk}$. Other factors, including different culture conditions and differences in screening and monitoring protocols, may also have contributed to the different harvest success rates in the 2 studies. It is also possible that the different outcomes may have resulted, at least in part, from different tolerances to WSSV. Indeed, tolerance has already been shown in Macrobrachium rosenbergii (Hameed et al. 2000), and WSSV is not pathogenic to the larval and early postlarval stages (<PL6) of Penaeus japonicus (Venegas et al. 1999). Like Tsai et al (1999), who successfully cultured a population of $P$. monodon with a light WSSV infection for more than 13 mo without any outbreak of WSS, results of both the present survey (Table 1) and of Withyachumnarnkul (1999) again suggest that some $P$. monodon populations may also be tolerant to WSSV at low infection levels.

WSSV tolerance may also help to account for the outcome in pond I (Fig. 2, Table 3) in the third part of the present study. The nauplii used to stock this pond had a WSSV detection rate of over $50 \%$, and feeding records (data not shown) suggest that an outbreak of WSS occurred within 3 wk of stocking. Nonetheless, at least $19.3 \%$ of the shrimp population survived this outbreak, perhaps partly because the dead shrimp would still have been quite small (between PL9 and PL30), and thus would have released only relatively low quantities of virus into the water. Not only did these survivors have the highest mean body weight at harvest, but the coefficient of variation of harvest weight was also the lowest (Table 3); that is, the survivors of the WSS outbreak subsequently appeared to thrive despite the continued presence of the virus.

Culture conditions were carefully monitored and controlled in all 3 of the ponds in the third part of this study. Although the growout periods all began in winter (November to February) and continued through to summer (May to July), and average monthly surface water temperature ranged from 23.9 to $28.5^{\circ} \mathrm{C}$, there were no abrupt increases or decreases in temperature: the largest change in surface water temperature from one day to the next was $<3^{\circ} \mathrm{C}$. Salinity was also carefully maintained between 30 and $33 \%$. One night in May, several inches of rain fell within a few hours and the shrimp came to the surface of the ponds (a behavior that is typically associated with environmental stress), but fresh seawater was immediately used to 
replace the desalinated pond-water and by morning, normal conditions had been restored. The feeding regimen too was designed to ensure that very little excess uneaten food was left in the pond, where it would have degraded the water quality. In particular, this means that if feeding levels drop off (as they did during the first month of culture in pond I, probably because of a WSSV outbreak, although this was not confirmed), there is no build-up of uneaten food to add to the environmental stress of the shrimps. Lastly, it should be noted that stocking density (50 to 58 shrimp ${ }^{-2}$ ) was medium rather than high. These observations suggest that in addition to stocking with healthy fry, good management practices, especially in regard to stocking density and maintenance of water quality through a measured feeding regimen, are likely to be critical for a successful growout period and harvest.

WSSV can be vertically transmitted from WSSVpositive spawners to their offspring (Lo et al. 1997, Tsai et al. 1999), and screening and selecting WSSV-negative brooders markedly reduces the chances of a subsequent outbreak of WSS (Satoh et al. 1999). Hsu et al (1999), who showed that most batches of eggs derived from WSSV-infected spawners were WSSV-positive and vice versa, have suggested that testing brooders for WSSV infection both before and after spawning, and testing samples of eggs for the presence of WSSV might both be effective screening strategies. The results shown in Table 2 are consistent with the brooder and egg WSSV infection data of Hsu et al. (1999) and further suggest that, instead of eggs, nauplii might be screened with equally good results. For screening purposes, nauplii offer several advantages over eggs: because of their phototropic behavior, they are relatively easy to collect and are less likely to be contaminated by dead eggs or other debris; at $30^{\circ} \mathrm{C}$, the nauplius stage in Penaeus monodon lasts for 36 to $48 \mathrm{~h}$ (versus only $\sim 12 \mathrm{~h}$ for eggs), which makes the whole screening process logistically easier; and lastly, nauplii contain yolk granules within their bodies and so, like eggs, they do not require feeding. The results shown in Table 3 further support the conclusion that testing nauplii is an effective and practical screening strategy for the commercial cultivation of $P$. monodon. The results (Tables $2 \& 3$ ) also suggest that the brooder's infection status might be a useful predictor in that the offspring from the 2 group B brooders (ponds II and III) were cultured successfully through to harvest whereas the offspring from the group A brooder (pond I) were not. This suggests that even if a brooder has only a light infection after spawning, it might be better not to use its offspring (regardless of their infection status) unless the brooder was also WSSVnegative before spawning, i.e., in group $B$ rather than group A.
Acknowledgements. This work was supported by the National Science Council under grants no. NSC88-2317B002-003 and NSC89-2317-B002-001. We thank Dr I-Chiu Liao, Director General, Taiwan Fisheries Research Institute, for his help in setting up the shrimp culture system and for his constructive suggestions. We thank Mr Chin-Te Cheng, from the Tainan City Animal Disease Diagnosis Control Center, for his help with the farm survey. We are indebted to Mr Paul Barlow for his helpful criticism of the manuscript.

\section{LITERATURE CITED}

Chou HY, Huang CY, Wang CH, Chiang HC, Lo CF (1995) Pathogenicity of a baculovirus infection causing white spot syndrome in cultured penaeid shrimp in Taiwan. Dis Aquat Org 23:165-173

Flegel TW (1997) Special topic review: major viral diseases of the black tiger prawn (Penaeus monodon) in Thailand. World J Microbiol Biotechnol 13:433-442

Global Aquaculture Alliance (1999a) Shrimp white spot virus confirmed in Central America. GAA Newsl 2(2)

Global Aquaculture Alliance (1999b) Shrimp white spot disease in Latin America - an update. GAA Newsl 2(3)

Hameed ASS, Charles MX, Anilkumar M (2000) Tolerance of Macrobrachium rosenbergii to white spot syndrome virus. Aquaculture 183:207-213

Hsu HC, Lo CF, Liu KF, Su MS, Kou GH (1999) Studies on effective PCR screening strategies for white spot syndrome virus (WSSV) detection in Penaeus monodon brooders. Dis Aquat Org 39:13-19

Lo CF, Kou GH (1998) Virus-associated white spot syndrome of shrimp in Taiwan: a review. Fish Pathol 33:365-371

Lo CF, Ho CH, Peng SE, Chen CH, Hsu HC, Chiu YL, Chang CF, Liu KF, Su MS, Wang CH, Kou GH (1996) White spot syndrome baculovirus (WSBV) detected in cultured and captured shrimp, crabs and other arthropods. Dis Aquat Org 27:215-225

Lo $\mathrm{CF}_{\text {, Ho } \mathrm{CH}}$, Chen $\mathrm{CH}$, Liu KF, Chiu YL, Yeh, PY, Peng SE, Hsu HC, Liu HC, Chang CF, Su MS, Wang $\mathrm{CH}_{\text {, Kou }}$ $\mathrm{GH}$ (1997) Detection and tissue tropism of white spot syndrome baculovirus (WSBV) in captured brooders of Penaeus monodon with a special emphasis on reproductive organs. Dis Aquat Org 30:53-72

Lo CF, Chang YS, Cheng CT, Kou GH (1998) PCR monitoring of cultured shrimp for white spot syndrome virus (WSSV) in growout ponds. In: Flegel TW (ed) Advances in shrimp biotechnology. National Center for Genetic Engineering and Biotechnology, Bangkok, p 281-286

Lo CF, Hsu HC, Tsai MF, Ho CH, Peng SE, Kou GH, Lightner DV (1999) Specific genomic fragment analysis of different geographical clinical samples of shrimp white spot syndrome virus. Dis Aquat Org 35:175-185

Maeda M, Itami T, Furumoto A, Hennig O, Imamura T, Kondo M, Hirono I, Takashi A, Takahashi Y (1998) Detection of penaeid rod-shaped DNA virus (PRDV) in wild-caught shrimp and other crustaceans. Fish Pathol 33:373-380

Otta SK, Shubha G, Joseph B, Chakraborty A, Karunasagar I, Karunasagar I (1999) Polymerase chain reaction (PCR) detection of white spot syndrome virus (WSSV) in cultured and wild crustaceans in India. Dis Aquat Org 38:67-70

Peng SE, Lo CF, Liu KF, Kou GH (1998) The transition from pre-patent to patent infection of white spot syndrome virus (WSSV) in Penaeus monodon triggered by pereiopod excision. Fish Pathol 33:395-400

Satoh J, Mushiake K, Mori KI, Arimoto M, Imaizumi K, 
Nishizawa T, Muroga K (1999) Occurrence of PAV (penaeid acute viremia) in seed production of kuruma prawn. Fish Pathol 34:33-38

Tsai MF, Kou GH, Liu HC, Liu KF, Chang CF, Peng SE, Hsu HC, Wang CH, Lo CF (1999) Long-term presence of white spot syndrome virus (WSSV) in a cultivated shrimp population without disease outbreaks. Dis Aquat Org 38: $107-114$

Editorial responsibility: Timothy Flegel,

Bangkok, Thailand
Venegas CA, Nonaka L, Mushiake K, Shimizu K, Nishizawa T, Muroga K (1999) Pathogenicity of penaeid rod-shaped DNA virus (PRDV) to kuruma prawn in different developmental stages. Fish Pathol 34:19-23

Withyachumnarnkul B (1999) Results from black tiger shrimp Penaeus monodon culture ponds stocked with postlarvae PCR-positive or -negative for white-spot syndrome virus (WSSV). Dis Aquat Org 39:21-27

Submitted: October 19, 2000; Accepted: April 5, 2001 Proofs received from author(s): September 18, 2001 